AJAR

3,2

190

Received 6 June 2018 Accepted 12 October 2018

\section{Changes of PTKP, PPh, PPN and PPnBM: its linkages on DJP East Java II}

\author{
Mienati Somya Lasmana and Reni Eka Isyatir Rodhiyah \\ Department of Accountancy, Universitas Airlangga, Surabaya, Indonesia
}

\begin{abstract}
Purpose - The purpose of this paper is to know the relevance between the changes in non-taxable income with the receipt of Income Tax Article 21, Income Tax Article 25/29, the receipt of value added tax and the receipt of luxury sales tax $\mathrm{r}(\mathrm{PPnBM})$.

Design/methodology/approach - Changes in non-taxable income have potentially reduced the receipt of Income Tax Article 21, Income Tax Article 25/29 of individual taxpayers, otherwise it increased value added tax and luxury sales tax receipts. This study used the descriptive qualitative approach, by conducting a simple case study based on actual data. Data analysis technique used is descriptive statistics and comparison analysis. Research conducted at the Kantor Wilayah Direktorat Jenderal Pajak Jawa Timur II.

Findings - The results show that the changes of non-taxable income in 2013 and 2015 did not affect the receipt of Income Tax Article 21 but the growth is slowed, while the receipt of Income Tax Article 25/29 increased. Originality/value - Value added tax and luxury sales tax receipts, increasing every year, slowed down in 2013, but increased higher in 2015.
\end{abstract}

Keywords Income Tax Article 21, Income Tax Article 25/29, Luxury sales tax, Non-taxable income, Value added tax

Paper type Research paper

\section{Introduction}

The government has been enforcing various tax instruments, one of which is granting tax incentives. A incentive given by the government is non-taxable income (PTKP). A press release from the Ministry of Finance of the Republic of Indonesia (2015) states that some considerations were made for this adjustment of non-taxable income (PTKP), such as increasing the adjusted Provincial Minimum Wage (UMP) and Regency/City Minimum Wage (UMK) in almost every region, significantly shifting price for necessities as a result of Subsidize Oil Fuel (BBM) adjustment policy, and also decelerating the trend of economic conditions. These policies were aimed at increasing the people's purchasing power; this could affect consumption rate and economic growth positively.

The terms of this adjustment of non-taxable income (PTKP) were constructed several times. From 1983 until 1999, provisions of PTKP were set in the Constitution of the Republic of Indonesia Number 7 of 1983 on Income Tax, and, recently, Ministry of Finance Regulation Number 122/PMK.010/2015 on the Adjustment of the Amount of Non-Taxable Income has been enacted.

Changes in non-taxable income have potentially reduced the receipt of Income Tax Article 21 and Article 25/29. On the other hand, these changes could hike up the take-home pay of tax bearers because of the less income tax payable to increase disposable income. A higher disposable income would liven up the aggregate demand so that Value Added Tax (PPN) and Sales Tax on Luxurious Goods (PPnBM) receipt also go up. Furthermore,

\footnotetext{
(C) Mienati Somya Lasmana. Published in Asian Journal of Accounting Research. Published by Emerald Publishing Limited. This article is published under the Creative Commons Attribution (CC BY 4.0) licence. Anyone may reproduce, distribute, translate and create derivative works of this article (for both commercial and non-commercial purposes), subject to full attribution to the original publication and authors. The full terms of this licence may be seen at $\mathrm{http} / /$ creativecommons.org/licences/by/4.0/legalcode
}

Asian Journal of Accounting Research

Vol. 3 No. 2, 2018 pp. 190-201

Emerald Publishing Limited 2443-4175

DOI 10.1108/AJAR-06-2018-0010 
a higher take-home pay for tax bearers does not mean that the earned income will be fully used as the disposable income; however, it could increase a tax bearer's saving. Nevertheless, the logic theory will not be the same as the reality itself. The research evidence showing this, like from Nuritomo (2011), Aprilina (2013), Ahmad (2014) and Andiyanto (2014), will be explained further.

The Regional Office of Directorate General of Tax of East Java II has a working area of East Java province, in the north, besides Surabaya, which contains 16 districts and 2 cities and supervises a Tax Office and 14 Pratama Tax Offices. In addition, the number of registered individual taxpayers grew above 600,000 in 2004 and $1 \mathrm{~m}$ in 2015. A descriptive qualitative approach with the study case method, which was conducted at the Regional Office of Directorate General of Tax of East Java II, is used for this research. Whereas, the data analysis technique used is descriptive statistics for describing or figuring out the collected data as it is, without making general conclusions, and also a comparative analysis is done in terms of affecting other factors in the given periods.

The next section of this paper provides the results of the research on the linkages between non-taxable income with Income Tax Article 21, Income Tax Article 25/29 for individual taxpayers, value added tax and luxury sales tax. The second section explains the literature review used, like relevant taxation conditions and previous studies with a similar topic. Next, the method used in this study is explained. Then, the research results in answering the research problems are explained. The paper ends with a conclusion.

Note that for the remaining part of the paper, non-taxable income will be shortened to PTKP, Income Tax Article 21 will be shortened to PPh Article 21, Income Tax Article 25/29 for individual taxpayer will be shortened to $\mathrm{PPh}$ Article 25/29 OP, value added tax will be shortened to PPN, and, lastly, sales tax on luxurious goods will be shortened to PPnBM. The choice of abbreviations is based on the original terminology of taxation in Indonesia. We believe that using these abbreviations will facilitate the Indonesian readers in understanding the contents of this paper.

\section{Literature review}

Non-taxable income (PTKP)

Non-taxable income (PTKP) is the given amount of income that is not subject to tax. PTKP is the income deduction for each individual taxpayer as a living cost, this goes along with Ilyas and Suhartono's (2011, p. 62) explanation. According to Andiyanto (2014, p. 3), if the net income of an individual taxpayer from his/her job is under the amount of PTKP, he/she will not be charged the PPh Article 25/29 and if he/she is a worker/employee or recipient of income as the object of PPh Article 21, so that income shall not be cut down PPh Article 21. The comparison from the change of rules regarding the adjustment of the amount of PTKP is provided in Table I.

\section{Inflation}

Inflation is simply interpreted as increasing prices in general and continually. The opposite of inflation is deflation, which occurs when the price level falls. The rate of inflation is the rate of change in the price level, which is usually calculated as the percentage of change per year, and is measured as follows:

$$
\text { Inflation rate }(\text { year } t)=\frac{\text { Price level }(\text { year } t)-\text { Price level }(\text { year } t-1)}{\text { Price level }(\text { year } t-1)} \times 100 \text {. }
$$

Samuelson et al. (2003, pp. 118-120) explain that the price level is the average weighing of prices of different goods and services within an economy. The government calculates the price level by compiling the price index, which is the average price of goods and services.

\section{Changes of PTKP, PPh, PPN and $\mathrm{PPnBM}$}




\begin{tabular}{|c|c|c|c|c|}
\hline Description & $\begin{array}{c}\text { Individual } \\
\text { taxpayer }\end{array}$ & Married & $\begin{array}{l}\text { Wife's income combined } \\
\text { with husband's income }\end{array}$ & $\begin{array}{c}\text { Dependent family } \\
\text { members within } \\
\text { blood related }\end{array}$ \\
\hline \multirow{11}{*}{$\begin{array}{l}\text { UU No. } 7 \text { Tahun } 1983 \\
\text { (1984-1993) } \\
\text { KMK RI No. 928/KMK.04/ } \\
\text { 1993 (1994) } \\
\text { UU No. 10 Tahun 1994 } \\
\text { (1995-1998) } \\
\text { KMK RI No. 361/KMK.04/ } \\
\text { 1998 (1999-2000) } \\
\text { UU No. 17 Tahun 2000 } \\
\text { (2001-2004) } \\
\text { PMK RI No. 564/KMK.03/ } \\
\text { 2004 (2005) } \\
\text { PMK RI No. 137/PMK.03/ } \\
\text { 2005 (2006-2008) } \\
\text { UU No. 36 Tahun 2008 } \\
\text { (2009-2012) } \\
\text { PMK RI No. 162/PMK.011/ } \\
\text { 2012 (2013-2014) } \\
\text { PMK RI No. 122/PMK.010/ } \\
\text { 2015 (2015-2016) }\end{array}$} & Rp960,000.00 & Rp480,000.00 & Rp960,000.00 & Rp480,000.00 \\
\hline & Rp1,728,000.00 & Rp864,000.00 & Rp1,728,000.00 & Rp864,000.00 \\
\hline & & & & \\
\hline & Rp1,728,000.00 & Rp864,000.00 & Rp1,728,000.00 & Rp864,000.00 \\
\hline & Rp.2,880,000.00 & Rp1,440,000.00 & Rp2,880,000.00 & Rp1,440,000.00 \\
\hline & Rp2,880,000.00 & Rp1,440,000.00 & Rp2,880,000.00 & Rp1,440,000.00 \\
\hline & Rp12,000,000.00 & Rp1,200,000.00 & Rp12,000,000.00 & Rp1,200,000.00 \\
\hline & Rp13,200,000.00 & Rp1,200,000.00 & Rp13,200,000.00 & Rp1,200,000.00 \\
\hline & Rp15,840,000.00 & Rp1,320,000.00 & $\mathrm{Rp} 15,840,000.00$ & Rp1,320,000.00 \\
\hline & $\operatorname{Rp} 24,300,000.00$ & $\mathrm{Rp} 2,025,000.00$ & Rp24,300,000.00 & Rp2,025,000.00 \\
\hline & Rp36,000,000.00 & Rp3,000,000.00 & Rp36,000,000.00 & Rp3,000,000.00 \\
\hline
\end{tabular}

Table I.

Comparison the amount of non-taxable income (PTKP) from 1983 to 2015
The price index is divided into three types. First, the consumer price index measures the cost of purchasing a standard basket of goods at different times. Second, the GDP deflator is the price of all goods and services produced within the country (consumption, investment, government spending and net exports) rather than a single component (such as consumption). Finally, the producer price index (PPI) is used to measure price levels at the wholesale or producer stage. The fixed scales used to calculate PPIs are the net sales of each commodity.

\section{Impact of PTKP changes to PPh, PPN, and PPnBM receipt}

Nuritomo (2011), in his research at KPP Yogyakarta Satu, found that the increase in PTKP affected the decrease in $\mathrm{PPh}$ Article 21 but did not affect the receipt of PPhOP, PPN and PPnBM. Research by Aprilina (2013) conducted at the Regional Office of the Directorate General of Tax of East Java I stated that the increase of PTKP negatively affected the receipt of $\mathrm{PPhOP}$ and $\mathrm{PPh}$ Article 21 in 2009, but did not have a negative impact when the PMK No. 564/KMK.03/2004 in 2005 and PMK No. 137/PMK.03/2005 in 2006. While the receipt of $\mathrm{PPN}$ and $\mathrm{PPnBM}$ tends to fluctuate, this does not follow the trend of PTKP increment. The research conducted by KPP Pratama Gorontalo by Fitri Ahmad (2014) explained that the change of PTKP applied positively affected the receipt of PPh Article 21 in KPP Pratama Gorontalo 37.9 percent, while the rest, equal to 62.1 percent, was influenced by other variables. In addition, research by Andiyanto (2014) conducted in two KPPs, namely, KPP Pratama Malang Selatan and KPP Pratama Banyuwangi, revealed that PTKP change does not lead to a decrease in the growth rate of the number of new WP OP. Changes in PTKP resulted in the receipt rate of PPh 21 in KPP Pratama Malang Selatan decreasing, but KPP Banyuwangi actually increased. The change of PTKP did not result in the decrease of realization of PPh 25/29 OP in KPP Pratama Malang Selatan and KPP Pratama Banyuwangi. 


\section{Research methods}

The approach used in this research is qualitative; the design of research is descriptive qualitative and the case study method is used. This study focuses on a particular unit that sees the linkages between the change in non-taxable income with the receipt of $\mathrm{PPh}$ Article 21, PPh Article 25/29 OP, PPN and PPnBM at the Regional Office of Directorate General of Taxes East Java II in the period 2009-2015.

\section{The scope of research}

The scope for this research is the receipt of PPh Article 21, PPh Article 25/29 OP, PPN and PPnBM at the Regional Office of Directorate General of Tax East Java II, which supervises 15 Tax Service Offices (KPP) including KPP Madya Sidoarjo, KPP Pratama Sidoarjo Utara, KPP Pratama Sidoarjo Selatan, KPP Pratama Sidoarjo Barat, KPP Pratama Gresik Utara, KPP Pratama Gresik Selatan, KPP Pratama Mojokerto, KPP Pratama Lamongan, KPP Pratama Tuban, KPP Pratama Bojonegoro, KPP Pratama Madiun, KPP Pratama Ponorogo, KPP Pratama Ngawi, KPP Pratama Bangkalan and KPP Pratama Pamekasan. Research data were taken from the data period of 2009 to 2015 because the data before the year 2009 were manual data, so it was quite difficult to get the data because it would have taken time.

\section{Place and time of research}

The research was conducted at the Regional Office of Directorate General of Tax East Java II, which is located at Jalan Raya Juanda No. 37 Semambung-Sidoarjo 61,254. The period for the research was from January to April 2016.

\section{Types and data sources}

The type of data collected in this study is quantitative and qualitative data. Quantitative data are data of target reports and realization of tax revenue in the period of 2009-2015, PPh Article 21, PPh 25/29 OP, PPN and PPnBM period 2009-2015 at Regional Office of Directorate General of Tax East Java II and other data related to this research. Meanwhile, qualitative data are the profile or history of the Regional Office of Directorate General of Tax East Java II establishment, the organizational structure, interview results with interviewees or employees who understand the research problem, as well as supporting literature and other data in this research.

The data sources used in this study are primary and secondary data. Primary data are results from interviews with individuals or the employees of the Regional Office of Directorate General of Tax East Java II. The secondary data in this research are Taxation Law, Regulation of Minister of Finance, Director General of Tax Regulation, literature books, journals, etc.

\section{Data collection procedures}

The data collection procedure begins with the Preliminary Survey, conducted to obtain a general description of the Regional Office of the Directorate General of Tax East Java II, and the investigation object is to find the problem of the relationship between the change of non-taxable income with receipt of $\mathrm{PPh}$ Article 21, $\mathrm{PPh}$ Article 25/29 OP, PPN and PPnBM. The next is a literature study to obtain the basic theory regarding the regulation in the change of PTKP, PPh Article 21, PPh Article 25/29 OP, PPN and PPnBM. The last is a field survey to obtain data or information directly from the Regional Office of Directorate General of Tax East Java II, which is useful for solving research problems. The field survey was conducted by interviews, observations and documentaries.

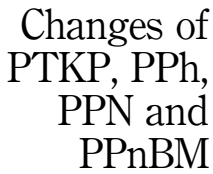


AJAR

3,2

194

\section{Analysis technique}

The data analysis techniques used in this study are descriptive statistics and comparative analysis. Comparative analysis is used to know, see and compare the change in the target growth rate and realization, as well as the level of receipt of $\mathrm{PPh}$ Article 21, PPh Article 25/29 OP, PPN and PPnBM each year during the period 2009-2015, using the previous year as a comparison. Growth rates and achievement rates are calculated as a percentage, and are measured as follows:

Growth Rates Target/Realization Revenue (year $t$ )

$=\frac{\text { Target } / \text { Realization Revenue }(\text { year } t)-\text { Target/Realization Revenue }(\text { year } t-1)}{\text { Target/Realization of Revenue }(\text { year } t-1)} \times 100 \%$

Achievement Rates upon Target Revenue (year $t$ )

$$
=\frac{\text { Realization of Revenue }(\text { year } t)}{\text { Target of Revenue }(\text { year } t)} \times 100 \% \text {. }
$$

Data analysis on the discussion was conducted in 2012 due to the changes in non-taxable income applied in 2013 and 2015. However, the data for the period of 2009-2011 are also analyzed and interpreted in terms of the effects that occur on the receipt of $\mathrm{PPh}$ Article 21, $\mathrm{PPh}$ Article 25/29 OP, PPN and PPnBM in the years after the enactment of the change of non-taxable income to various factors.

The steps taken by obtaining and collecting reports or data receipt of PPh Article 21, PPh 25/29 OP, PPN and PPnBM period 2009-2015 from the Regional Office of Directorate General of Tax East Java II, processing or organizing data as well as comparing PPh data for the period 2009-2015 then presents it on the year to year basis and inter-KPP, analyzing and interpreting the processed data that has been done and the factors which are affected in the change of PPh Article 21, PPh 25/29 OP, PPN and PPnBM within assisted interview results from employees of the Regional Office of Directorate General of Tax East Java II, and giving conclusions and suggestions based on results of the data analysis.

\section{Results and discussion}

\section{Profile of Regional Office of Directorate General of Tax East Java II}

Based on the Regulation of the Ministry of Finance No. 206.2/PMK.01/2014 on Organization and Working Procedure of Vertical Institution of Directorate General of Taxation, Regional Office of Directorate General of Tax East Java II supervises one Tax Service Office (KPP) Madya, namely, KPP Madya Sidoarjo. It also oversees 14 Tax Service Offices (KPP) Pratama and seven Extension Services and Taxation Consultation Office (KP2KP). Each KPP Pratama has administrative areas, such as KPP Pratama Bojonegoro serving tax activities for Bojonegoro and KPP Pratama Lamongan for Lamongan.

\section{Income Tax Revenue Article 21 period 2009-2015}

PTKP in the period of 2009-2015 has changed twice (Table I). Details of Income Tax Article 21 period 2009-2015 on 14 KPP Pratama and one of KPP Madya in the Regional Office of Directorate General of Tax East Java II0 are presented in Figure 1 and Table II.

Based on the data in Figure 1, it can be seen that the revenue of Income Tax Article 21 in 2009 to 2012 experienced growth with varying levels. The changes in PTKP that occurred in 2009 with the enactment of Law No. 36 of 2008 should have a decreasing effect on the realization of $\mathrm{PPh}$ Article 21 in the year of its enactment and subsequent years. Increase in PTKP causes the taxable income to be decreased so that the amount of 


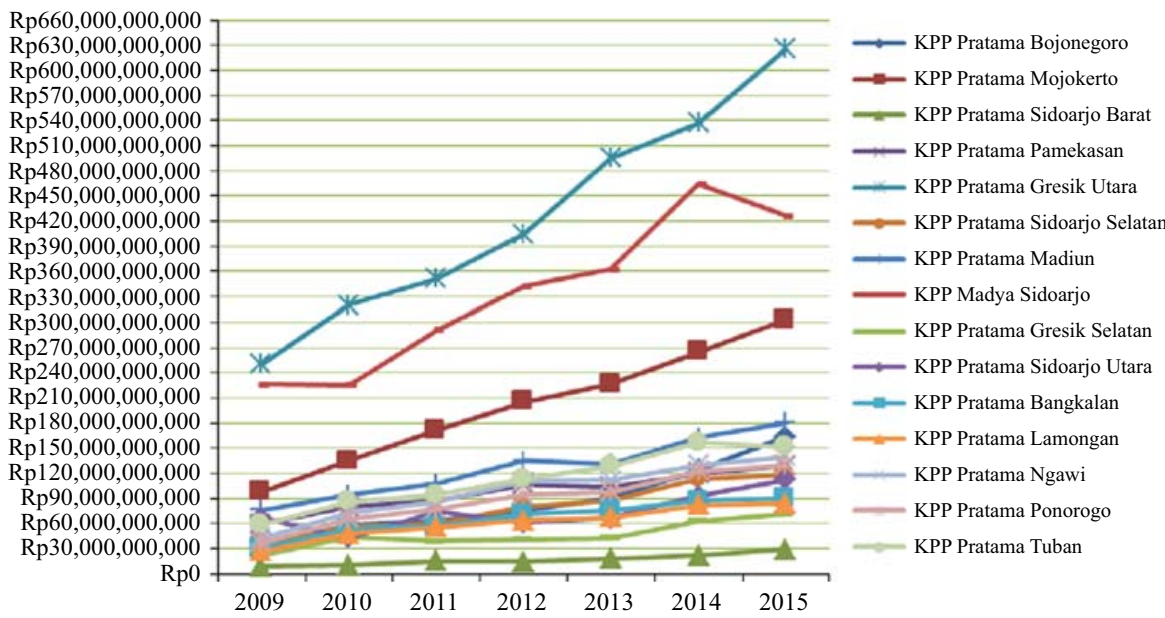

Source: Regional Office of Directorate General of Tax East Java II's Data, processed by writer

\begin{tabular}{lcccc}
\hline Year & Target (Rp) & Increase/decrease (\%) & Realization (Rp) & Increase/decrease (\%) \\
\hline 2009 & $766,646,200,000$ & - & $1,073,240,478,976$ & - \\
2010 & $1,158,905,464,000$ & 51.17 & $1,397,681,060,240$ & 30.23 \\
2011 & $1,317,440,550,000$ & 13.68 & $1,630,567,437,274$ & 16.66 \\
2012 & $2,087,598,281,219$ & 58.46 & $1,919,242,472,995$ & 17.70 \\
2013 & $2,530,574,665,999$ & 21.22 & $2,105,237,026,623$ & 9.69 \\
2014 & $2,410,746,969,999$ & -4.74 & $2,542,952,699,229$ & 20.79 \\
2015 & $3,342,110,201,000$ & 38.63 & $2,754,834,889,193$ & 8.33
\end{tabular}

Changes of PTKP, PPh, $\mathrm{PPN}$ and $\mathrm{PPnBM}$

195

Figure 1.

Tax Income Revenue Article 21 period 2009-2015

Table II.

Increasing/decreasing target and realization revenue of $\mathrm{PPh}$ Article 21 period 2009-2015 on Regional Office of Directorate General of Tax East Java II

$\mathrm{PPh}$ Article 21 that is deposited is also decreased. However, in most of the KPPs in the Regional Office of the Directorate General of Tax East Java II, the income tax revenue of Article 21 increased in 2010 to 2012, and also in 2014. This increase is caused by change in UMK (Minimum Wage City/District), as well as salary payments of PNS, TNI and POLRI increased every year.

In 2013 and 2015, most of PPh revenues of Article 21 of the Tax Office experienced lower growth than in the previous year due to the rise in PTKP and the declining employment rate. However, slower performance is temporary. In 2014, the revenue of $\mathrm{PPh}$ Article 21 was due to almost all of the KPP experiencing higher growth compared to the previous year.

The target of PPh receipts Article 21 tends to increase during the period of 2009-2015. However, in 2014, it decreased by 4.74 percent due to the growth of realization of $\mathrm{PPh}$ Article 21 in 2013 which only amounted to 9.69 percent and the achievement of the realization of $\mathrm{PPh}$ Article 21 target for 2013 was 8.01 percent lower than the previous year. In 2011, revenue realization experienced a growth of only 16.66 percent due to the large decline in the number of the working population. The growth in 2012 amounted to 17.70 percent and in 2014, it amounted to 20.79 percent influenced by an increase in UMK as well as basic salaries of PNS, TNI and POLRI. The growth of realization is lower than the previous year 2013, which amounted to 9.69 percent and in 2015 , which only amounted to 8.33 percent compared to the previous year due to the enactment of regulation of PTKP adjustments 
AJAR 3,2

196

Figure 2.

Income Tax Revenue Article 25/29 of individual person Period 2009-2015

Figure 3.

Number of registered individual taxpayers period 2009-2015 according to the PMK No. 162/PMK.011/2012 and No. 122/PMK.010/2015 in 2015, as well as the termination of employment which seems quite influential on the performance of $\mathrm{PPh}$ Article 21 revenue in that year.

Income Tax Revenue Article 25/29 of individual person period 2009-2015

The details of the comparison between the receipt of $\mathrm{PPh}$ Article 25/29 of the individual person and the number of registered and effective individual taxpayers for the period 2009-2015 in each KPP Pratama in the Regional Office of the Directorate General of Tax of East Java II are presented in Figures 2-4.

Based on the data obtained from the Regional Office of the Directorate General of Tax East Java II, from 14 KPP Pratama, the number of registered OP taxpayers in each KPP always increases with different growth rates each year. Most registered OP taxpayers are at

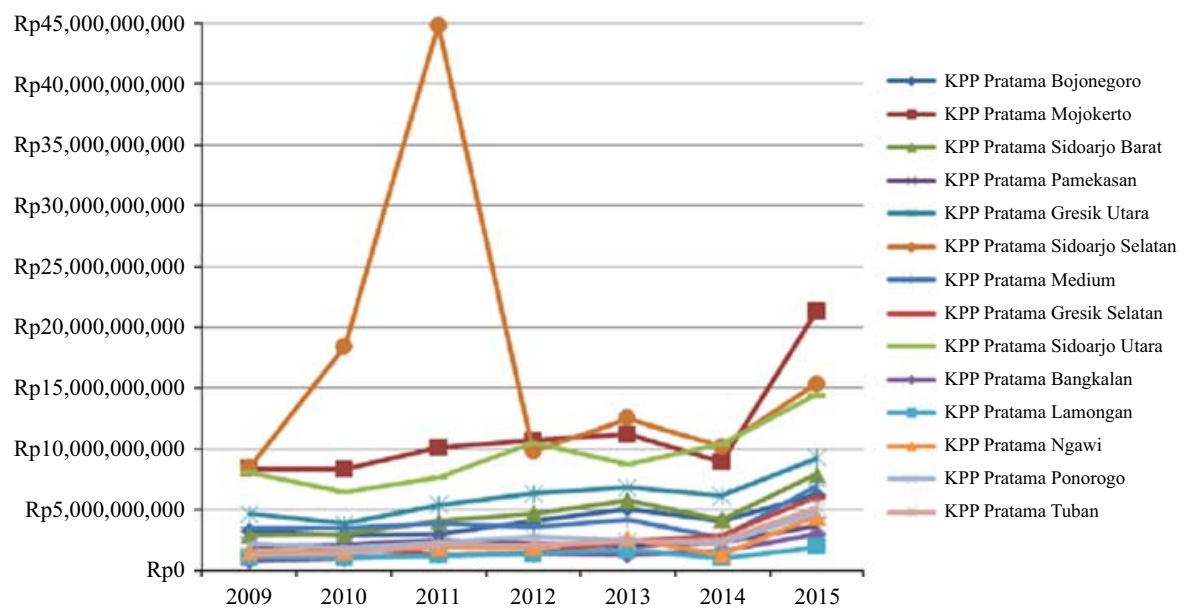

Source: Regional Office of Directorate General of Tax East Java II's Data, processed by writer

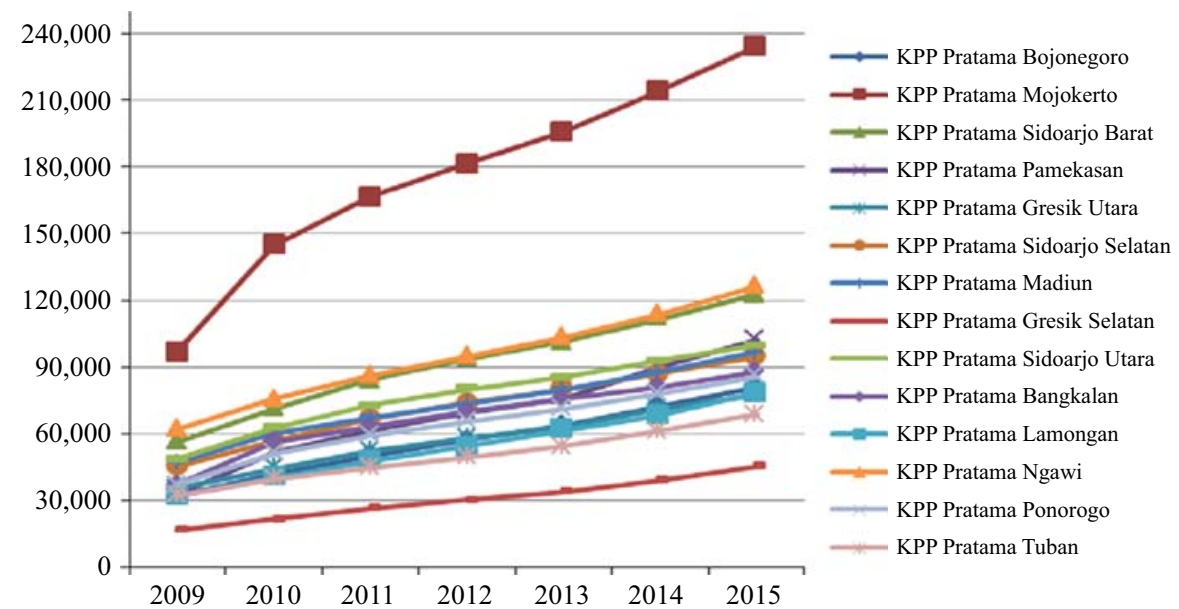

Source: Regional Office of Directorate General of Tax East Java II's Data, processed by writer 


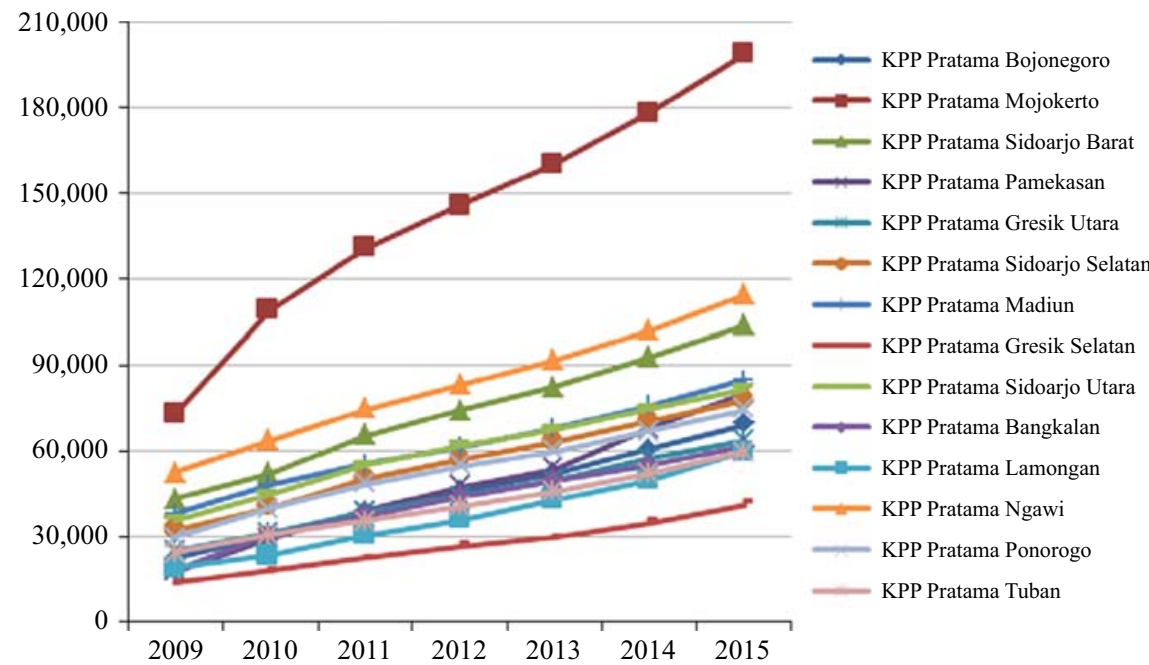

Source: Regional Office of Directorate General of Tax East Java II's Data, processed by writer
Changes of PTKP, PPh, PPN and $\mathrm{PPnBM}$ 197

Figure 4. Number of effective individual taxpayers period 2009-2015

KPP Pratama Mojokerto, which reached 198,156 OP taxpayers. The change in PTKP is directly proportional to the number of registered OP taxpayers in each KPP Pratama at the DJP Regional Office of East Java II, as well as the number of effective OP taxpayers. However, the increase in the number of registered OP taxpayers and effective OP taxpayers is not always directly proportional to the revenue of PPh Article 25/29 OP.

Based on Table III, the target of PPh Revenue Article 25/29 OP fluctuates every year. In 2013, to coincide with the enactment of changes in PTKP according to PMK No. 162/ PMK.011/2012, the realization of PPh Article 25/29 OP experienced a growth of 10.00 percent, in line with the increasing number of WP OP registered and effective. Realization of $\mathrm{PPh}$ Article 25/29 OP 2014 decreased by 12.21 percent, which was influenced by the new type of payment of PPh Final 1 percent in accordance with PP No.46 of 2013 on the income tax on income from the business received or obtained by taxpayers who have certain gross distribution. While in the year 2015, the performance of PPh Revenue Article 25/29 OP reached 82.38 percent growth because it was influenced by the implementation of PMK No. 91/PMK.03/2015 on the Reduction or Elimination of Administrative Sanctions for Delay in Submission of Notification Letter, Revision of Notice Letter, and Delay of Payment or Tax Deposit. The existence of the enforcement of this rule caused the individual taxpayers in droves to pay or settle tax payable PPh Article 25/29 OP.

\begin{tabular}{lcccc}
\hline Year & Target $(\mathrm{Rp})$ & Increase/Decrease $(\%)$ & Realization $(\mathrm{Rp})$ & Increase/Decrease $(\%)$ \\
\hline 2009 & $64,391,708,000$ & - & $49,487,412,017$ & - \\
2010 & $61,546,183,000$ & -4.42 & $57,541,013,481$ & 16.27 \\
2011 & $70,741,270,000$ & 14.94 & $91,537,138,624$ & 59.08 \\
2012 & $109,959,843,552$ & 55.44 & $62,940,532,318$ & -31.24 \\
2013 & $159,160,969,000$ & 44.74 & $69,234,208,265$ & 10.00 \\
2014 & $76,796,275,999$ & -51.75 & $60,777,908,174$ & -12.21 \\
2015 & $71,792,867,000$ & -6.52 & $110,849,642,892$ & 82.38
\end{tabular}

Source: Regional Office of Directorate General of Tax East Java II's data, processed by writer

Table III.

Increasing/decreasing target and realization revenue of $\mathrm{PPh}$ Article 25/29 OP period 2009-2015 on Regional Office of Directorate General of Tax East Java II 
AJAR

3,2

198

Revenue of PPN and PPnBM period 2009-2015

The graph of PPN and PPnBM revenues from 2009 to 2015 in 14 Tax Office (KPP) Pratama and 1 Tax Office (KPP) Madya in the Regional Office of Directorate General of Tax East Java II is presented in Figure 5.

Based on the data in Figure 5, it can be seen that the revenue of PPN and PPnBM in the period 2009-2015 fluctuated, not following the trend of changes in PTKP. This can be demonstrated in 2009 until 2012 after the enactment of new PTKP in accordance with Law No. 36 Year 2008, as well as in 2014 after the enactment of new PTKP according to PMK RI. 162/PMK.011/2012, the realization of PPN and PPnBM revenue fluctuated in all KPP. In 2013, the new PTKP came into force and the receipt of PPN and PPnBM of several KPPs has decreased. It is also due to a high inflation rate. Whereas in 2015, the realization of PPN and $\mathrm{PPnBM}$ revenues increased with varying growth rates due to the implementation of PMK No. 122/PMK.010/2015 and the rate of inflation decreased from the previous year.

Based on Table IV, the realization of PPN and PPnBM revenues period 2009 until 2015, PPN and PPnBM receipts reached 100 percent of the target only once: in 2012, it amounted to 112.71 percent. This is in line with the economic growth rate of East Java in 2012, which reached the highest growth rate in the period 2009-2015, that is 5.01 percent (2009), 6.67 percent (2010), 7.23 percent (2011), 7.27 percent (2012), 6.55 percent (2013), 6.1 percent (2014) and 5.44 percent (2015).

Figure 5.

Revenue of PPN dan PPnBM Period 2009-2015

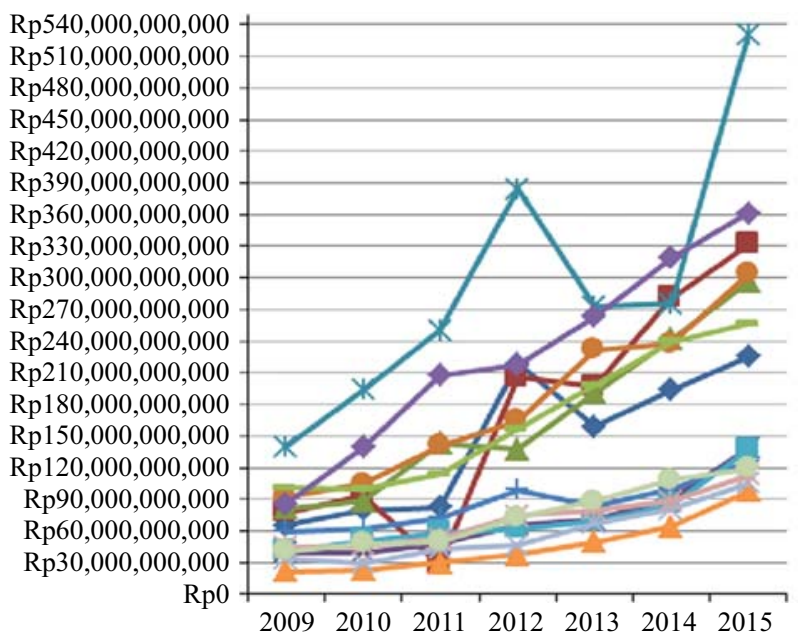

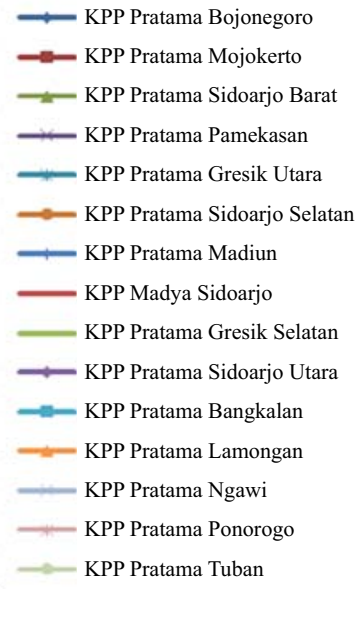

Table IV.

Achievement in revenue of PPN and PPnBM period 2009-2015 on office of directorate general of tax East Java II

\begin{tabular}{lccc}
\hline Tahun & Target $(\mathrm{Rp})$ & Realisasi $(\mathrm{Rp})$ & Persentase Pemenuhan Target $(\%)$ \\
\hline 2009 & $2,478,074,520,000$ & $2,326,607,806,864$ & 93.89 \\
2010 & $3,347,836,638,215$ & $2,401,813,057,941$ & 71.74 \\
2011 & $3,391,851,187,586$ & $2,972,572,077,165$ & 87.64 \\
2012 & $3,923,653,079,001$ & $4,422,465,101,292$ & 112.71 \\
2013 & $5,575,212,160,998$ & $5,011,725,030,781$ & 89.89 \\
2014 & $6,269,458,576,997$ & $5,570,708,973,424$ & 88.85 \\
2015 & $8,284,284,975,000$ & $6,834,800,426,728$ & 82.50
\end{tabular}


While the achievement of the lowest PPN and PPnBM revenue occurred in 2010, it amounted to 71.74 percent. This is because the inflation rate in 2010 was quite high in the range of 6-7 percent, compared to the previous year which seemed to affect the achievement of PPN and PPnBM revenue in 2010.

The data in Table V show that the revenue of Income Tax Article 21 and Income Tax Article 25/29 OP increased in the years of implementation of PTKP. This also happened to the revenue of PPN and PPnBM. However, in 2013, PPN and PPnBM revenues only grew by 13.32 percent; lower than in the previous year, although the regulation on new PTKP was enacted in that year.

\section{Conclusion}

Based on the results of the research above, the increase of PTKP does not cause a decrease in the receipt of PPh Article 21 in 2013 when the enactment of PMK No. 162/PMK.011/2012, only the growth of PPh receipt Article 21 slows down; a similar trend was observed in 2015, when the PMK No. 122/PMK.010/2015 was enacted. After the enactment of Law Number 36 Year 2008, the $\mathrm{PPh}$ receipt Article 21 grew with varying levels following the economic conditions.

Increase in PTKP is proportional to the increase in the number of registered individual taxpayers and effective individual taxpayers. However, an increase in the number of registered individual taxpayers and effective individual taxpayers is not always proportional to the revenue of the PPh Article 25/29 OP. Coinciding with the increase of $\mathrm{PTKP}$, the revenue of $\mathrm{PPh}$ Article 25/29 in 2013 and 2015 increased. Increase in $\mathrm{PPh}$ Revenue Article 25/59 also could not be separated from the intensification and extensification efforts, which were conducted by the Directorate General of Taxation.

Each year, PPN and PPnBM receipts tend to increase with varying growth rates and do not follow the trend of increasing PTKP. The revenues of PPN and PPnBM also cannot be separated from the economic conditions.

So it can be seen that the change in PTKP does not have a significant effect on the revenue of PPh Article 21, PPh Article 25/29, as well as PPN and PPnBM. This is because there are still other factors that influence the tax revenue, such as other tax policies and the indonesian economy. Conversely, the effect of PTKP changes is proportional to the number of registered taxpayers and effective OP taxpayers. This research is expected to give input and consideration for Directorate General of Tax on the change of non-taxable income to improve its performance in trying to increase $\mathrm{PPh}$ Article 21, PPh Article 25/29 OP, PPN and PPnBM either through intensification or extensification.

\begin{tabular}{lcccccc}
\hline Year & $\begin{array}{c}\text { PPh Article 21 } \\
(\mathrm{Rp})\end{array}$ & $\begin{array}{c}\text { Increase/ } \\
\text { decrease (\%) }\end{array}$ & $\begin{array}{c}\text { PPh Article 25/29 } \\
\text { OP (Rp) }\end{array}$ & $\begin{array}{c}\text { Increase/ } \\
\text { decrease (\%) }\end{array}$ & $\begin{array}{c}\text { PPN and PPnBM } \\
(\mathrm{Rp})\end{array}$ & $\begin{array}{c}\text { Increase/ } \\
\text { decrease (\%) }\end{array}$ \\
\hline 2009 & $1,073,240,478,976$ & - & $49,487,412,017$ & - & $2,326,607,806,864$ & - \\
2010 & $1,397,681,060,240$ & 30.23 & $57,541,013,481$ & 16.27 & $2,401,813,057,941$ & 3.23 \\
2011 & $1,630,567,437,274$ & 16.66 & $91,537,138,624$ & 59.08 & $2,972,572,077,165$ & 23.76 \\
2012 & $1,919,242,472,995$ & 17.70 & $62,940,532,318$ & -31.24 & $4,422,465,101,292$ & 48.78 \\
2013 & $2,105,237,026,623$ & 9.69 & $69,234,208,265$ & 10.00 & $5,011,725,030,781$ & 13.32 \\
2014 & $2,542,952,699,229$ & 20.79 & $60,777,908,174$ & -12.21 & $5,570,708,973,424$ & 11.15 \\
2015 & $2,754,834,889,193$ & 8.33 & $110,849,642,892$ & 82.38 & $6,834,800,426,728$ & 22.69
\end{tabular}

\section{Changes of PTKP, PPh, PPN and $\mathrm{PPnBM}$}

\section{9}

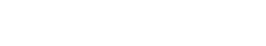


AJAR

3,2

\section{References}

Ahmad, F. (2014), "Pengaruh Perubahan Penghasilan Tidak Kena Pajak Terhadap Penerimaan Pajak Penghasilan Pasal 21 di KPP Pratama Gorontalo", Karya Ilmiah Mahasiswa Fakultas Ekonomi dan Bisnis Universitas Negeri Gorontalo, Vol. 2 No. 1, pp. 1-12, available at: http://kim.ung.ac.id/ index.php/KIMFEB/article/view/15476/14722 (diakses Januari 12, 2016).

Andiyanto, D. (2014), "Analisis Perubahan Penghasilan Tidak Kena Pajak (PTKP) Terhadap Tingkat Pertumbuhan Jumlah Wajib Pajak Orang Pribadi Dan Penerimaan Pajak Penghasilan (Studi Pada KPP Pratama Malang Selatan Dan KPP Pratama Banyuwangi Periode 2009-2013)", Jurnal Mahasiswa Perpajakan, Vol. 2 No. 1, pp. 1-9, available at: http://perpajakan.studentjournal.ub.ac. id/index.php/perpajakan/article/view/40 (diakses Januari 12, 2016).

Aprilina, R.R.F. (2013), "Kaitan Kenaikan Penghasilan Tidak Kena Pajak Dengan Penerimaan PPh Pasal 21, PPh OP, PPN, dan PPnBM Kantor Wilayah Direktorat Jenderal Pajak Jawa Timur I", Skripsi tidak diterbitkan, Surabaya Universitas Airlangga S1 Akuntansi.

Ilyas, W.B. and Suhartono, R. (2011), Hukum Pajak Material I: Seri Pajak Penghasilan, Salemba Humanika, Jakarta.

Nuritomo (2011), "Pengaruh Peningkatan Penghasilan Tidak Kena Pajak Terhadap Penerimaan Pajak Studi Pada KPP Yogyakarta Satu”, Jurnal Ilmiah Akuntansi dan Bisnis, Vol. 6 No. 1, pp. 1-23, available at: http://ojs.unud.ac.id/index.php/jiab/article/view/2642/1857, diakses 12 Januari 2016

Samuelson, P.A. and Nordhaus, W.D. (2003), Imu Mikroekonomi, Media Global Edukasi, Edisi Tujuh Belas, Jakarta.

\section{Further reading}

Anshori, M. and Iswati, S. (2009), Metodologi Penelitian Kuantitatif, Pusat Penerbitan dan Percetakan Unair (AUP), Surabaya.

Bungin, B. (2008), Penelitian Kualitatif: Komunikasi, Ekonomi, Kebijakan Publik, dan Ilmu Sosial Lainnya, Edisi Pertama., Kencana, Jakarta.

Divisi Kajian Moneter (2013), Kajian Ekonomi Regional Jawa Timur Triwulan IV-2013, Bank Sentral Republik Indonesia, Surabaya.

Divisi Kajian Moneter (2014), Kajian Ekonomi Regional Jawa Timur Triwulan IV-2014, Bank Sentral Republik Indonesia, Surabaya.

Divisi Kajian Moneter (2015), Kajian Ekonomi Regional Jawa Timur Triwulan IV-2015, Bank Sentral Republik Indonesia, Surabaya.

Idrus, M. (2009), Metode Penelitian Ilmu Sosial, Edisi Kedua., Erlangga, Jakarta.

Pusat Kebijakan Pendapatan Negara (2015), Siaran Pers Peraturan Menteri Keuangan Republik Indonesia Nomor 122/PMK.010/2015 tentang Penyesuaian Besarnya Penghasilan Tidak Kena Pajak (PTKP), Kementrian Keuangan Republik Indonesia, Jakarta.

Republik Indonesia (1983a), “Undang-Undang Nomor 7 Tahun 1983 tentang Pajak Penghasilan”.

Republik Indonesia (1983b), “Undang-Undang Nomor 8 Tahun 1983 tentang Pajak Pertambahan Nilai Barang dan Jasa Dan Pajak Penjualan Atas Barang Mewah”.

Republik Indonesia (1993), "Keputusan Menteri Keuangan Republik Indonesia Nomor 928/KMK.04/ 1993 tentang Faktor Penyesuaian Besarnya Penghasilan Tidak Kena Pajak".

Republik Indonesia (1994), "Undang-Undang Nomor 10 Tahun 1994 tentang Perubahan Atas UndangUndang Nomor 7 Tahun 1983 tentang Pajak Penghasilan Sebagaimana Telah Diubah Dengan Undang-Undang Nomor 7 Tahun 1991”.

Republik Indonesia (1998), "Keputusan Menteri Keuangan Republik Indonesia Nomor 361/KMK.04/ 1998 tentang Faktor Penyesuaian Besarnya Penghasilan Tidak Kena Pajak".

Republik Indonesia (2000), "Undang-Undang Nomor 17 Tahun 2000 tentang Perubahan Ketiga Atas Undang-Undang Nomor 7 Tahun 1983 tentang Pajak Penghasilan”.

Republik Indonesia (2001), "Perubahan Ketiga Undang-Undang Dasar Negara Republik Indonesia 1945”. 
Republik Indonesia (2003), “Undang-Undang Nomor 13 Tahun 2003 tentang Ketenagakerjaan”.

Republik Indonesia (2004), "Peraturan Menteri Keuangan Republik Indonesia Nomor 564/KMK.03/ 2004 tentang Penyesuaian Besarnya Penghasilan Tidak Kena Pajak".

Republik Indonesia (2005), "Peraturan Menteri Keuangan Republik Indonesia Nomor 137/PMK.03/2005 tentang Penyesuaian Besarnya Penghasilan Tidak Kena Pajak".

Republik Indonesia (2007), "Undang-Undang Nomor 28 Tahun 2007 tentang Perubahan Ketiga Atas Undang-Undang Nomor 6 Tahun 1983 tentang Ketentuan Umum dan Tata Cara Perpajakan”.

Republik Indonesia (2008), "Undang-Undang Nomor 36 Tahun 2008 tentang Perubahan Keempat Atas Undang-Undang Nomor 7 Tahun 1983 tentang Pajak Penghasilan”.

Republik Indonesia (2009), "Undang-Undang Nomor 42 Tahun 2009 tentang Perubahan Ketiga Atas Undang-Undang Nomor 8 Tahun 1983 tentang Pajak Pertambahan Nilai Barang dan Jasa Dan Pajak Penjualan Atas Barang Mewah”.

Republik Indonesia (2012), "Peraturan Menteri Keuangan Republik Indonesia Nomor 162/PMK.011/ 2012 tentang Penyesuaian Besarnya Penghasilan Tidak Kena Pajak”.

Republik Indonesia (2013a), "Peraturan Menteri Keuangan Republik Indonesia Nomor 107/PMK.011/ 2013 tentang Tata Cara Penghitungan, Penyetoran, Dan Pelaporan Pajak Penghasilan Atas Penghasilan Dari Usaha Yang Diterima Atau Diperoleh Wajib Pajak Yang Memiliki Peredran Bruto Tertentu".

Republik Indonesia (2013b), "Peraturan Pemerintah Republik Indonesia Nomor 46 Tahun 2013 tentang Pajak Penghasilan Atas Penghasilan Dari Usaha Yang Diterima Atau Diperoleh Wajib Pajak Dengan Peredaran Bruto Tertentu".

Republik Indonesia (2014a), "Peraturan Menteri Keuangan Republik Indonesia Nomor 206.2/PMK.01/ 2014 tentang Organisasi Dan Tata Kerja Instansi Vertikal Direktorat Jenderal Pajak".

Republik Indonesia (2014b), "Peraturan Pemerintah Republik Indonesia Nomor 22 Tahun 2014 tentang Perubahan Atas Peraturan Pemerintah Nomor 41 Tahun 2013 tentang Barang Kena Pajak Yang Tergolong Mewah Berupa Kendaraan Bermotor Yang Dikenai Pajak Penjualan Atas Barang Mewah”.

Republik Indonesia (2015a), "Peraturan Direktur Jenderal Pajak Nomor: PER-32/PJ/2015 tentang Pedoman Teknis Tata Cara Pemotongan, Penyetoran, dan Pelaporan Pajak Penghasilan Pasal 21 dan/atau Pajak Penghasilan Pasal 26 Sehubungan dengan Pekerjaan, Jasa, dan Kegiatan Orang Pribadi”.

Republik Indonesia (2015b), "Peraturan Menteri Keuangan Republik Indonesia Nomor 91/PMK.03/2015 tentang Pengurangan Atau Penghapusan Sanksi Administrasi Atas Keterlambatan Penyampaian Surat Pemberitahuan, Pembetulan Surat Pemberitahuan, Dan Keterlambatan Pembayaran Atau Penyetoran Pajak".

Republik Indonesia (2015c), "Peraturan Menteri Keuangan Republik Indonesia Nomor 122/PMK.010/ 2015 tentang Penyesuaian Besarnya Penghasilan Tidak Kena Pajak”.

Suandy, E. (2011), Hukum Pajak, Edisi Kelima: Salemba Empat, Jakarta.

Sugiyono (2009), Metode Penelitian Bisnis (Pendekatan Kuantitatif, Kualitatif, dan R\&D), Alfabeta, Bandung.

Waluyo (2011), Perpajakan Indonesia, Edisi Kesepuluh Buku Dua., Salemba Empat, Jakarta.

Waluyo (2014), Perpajakan Indonesia, Edisi Kesebelas Buku Satu., Salemba Empat, Jakarta.

\section{Corresponding author}

Mienati Somya Lasmana can be contacted at: mienati-s-1@feb.unair.ac.id

For instructions on how to order reprints of this article, please visit our website:

www.emeraldgrouppublishing.com/licensing/reprints.htm

Or contact us for further details: permissions@emeraldinsight.com

\section{Changes of PTKP, PPh, PPN and PPnBM}

\section{$+$}

